Wojciech Stawiszyński

\title{
Polska bibliografia Antyku Chrześcijańskiego 2020 $\mathrm{Z}$ uzupelnieniami za rok 2019
}

\section{Działy tematyczne}

1. Prace zbiorowe (antologie tekstów i opracowania)

2. Bibliografie i problemy metodologiczne

3. Prace ogólne, historie literatury

4. Historia wspólnot, instytucji, okresów historycznych, regionów

5. Historia doktryn (teologia i filozofia)

6. Liturgia

7. Hagiografia, monastycyzm i historia duchowości

8. Archeologia i historia sztuki

9. Biblia

9.1. Apokryfy

9.2. Gnostycyzm

10. Patrystyka i średniowiecze (łacińskie i bizantyńskie)

10.1 Przekłady

10.2. Opracowania

11. Autorzy

12. Recenzje, omówienia

13. Sprawozdania

14. Wybrane publikacje z zakresu kultury klasycznej

14.1 Przekłady

14.2. Opracowania 


\section{Prace zbiorowe (antologie tekstów i opracowania)}

Apokryfy Nowego Testamentu, t 1, część 1 i 2: Ewangelie apokryficzne, red. M. Starowieyski, wyd. 3, Kraków: Wydawnictwo WAM, 2020.

Apokryfy Nowego Testamentu, t. 2, część 1 i 2: Apostołowie, red. M. Starowieyski, wyd.

3, Kraków: Wydawnictwo WAM, 2020.

Apokryfy Nowego Testamentu, t. 3: Listy i apokalipsy chrześcijańskie. Apokryfy syryjskie, red. M. Starowieyski, wyd. 3, Kraków: Wydawnictwo WAM, 2020.

Byzantina et Slavica. Studies in Honour of Professor Maciej Salamon, red. S. Turlej -

M. Stachura - J.B. Kołoczek - A. Izdebski, Kraków: Towarzystwo Wydawnicze „Historia Iagellonica”, 2020.

"Corona Mystica», Adwent-w oczekiwaniu na przyjściu Pana. Święte tajemnice wedtug Ojców Kościoła. Efrem Syryjski, Rabulas z Edessy, Roman Melodos, tł. J. Kania, Kraków: Wydawnictwo Serafin, 2020.

Dokumenty synodów od 553 do 600 roku/Acta Synodalia ab anno 553 ad annum 600, opr. H. Pietras, Synody i Kolekcje Praw/Synodi et Collectiones Legum 12 - ŹMT 83, Kraków: Wydawnictwo WAM, 2020.

Grześkowiak R. - Gwioździk J. - Nowicka-Struska A., Karmelitańskie adaptacje "Pia desideria» Hermana Hugna z XVII $i$ XVIII w., Warszawa: Wydawnictwo Neriton, 2020.

Maryja w Biblii i refleksji Ojców Kościoła, red. P. Wygralak, Teologia Patrystyczna 17, Poznań: Wydział Teologiczny UAM, 2020.

Maryja $w$ Biblii $i$ w Kościele, red. P. Labuda, Tarnów: Wydawnictwo Biblos, 2020.

Męczennicy pierwszych wieków chrześcijaństwa, red. M. Starowieyski, Ojcowie Żywi 24, Kraków: Wydawnictwo WAM, Kraków 2020.

Św. Efrem, Pseudo-Efrem, św. Jakub z Sarug, Syryjskie Hymny o Maryi, tł. W. Kania - A. Bielenin, opr. M. Starowieyski, Biblioteka Ojców Kościoła 36, Kraków: Wydawnictwo M, 2020.

Święty Hieronim: egzegeta, dogmatyk, polemista..., red. P. Wygralak, Teologia Patrystyczna 16, Poznań: Wydział Teologiczny UAM, 2019.

Wygralak P., Ojców Kościoła 31 wskazań na drogach duszpasterskiej posługi, Poznań:

Uniwersytet im. Adama Mickiewicza w Poznaniu Wydział Teologiczny, 2020.

Zasady życia $w$ klasztorze mniszym wedtug Św. Bernarda z Clairvaux $i$ ocena zakonu cystersów przez Św. Hildegardę z Bingen, opr. A.M. Wyrwa, Poznań: Wydawnictwo Instytutu Historii UAM, 2020.

Źródła do epikurejskiej etyki wychowania, red. M. Wasilewski, Gorzów Wielkopolski: Akademia im. Jakuba z Paradyża, 2020. 


\section{Bibliografie i problemy metodologiczne}

Czyżewski B., Wkład środowiska wielkopolskiego w rozwój patrologii, PST 35 (2019) s. 121-138.

Dyk S., Aktualność homilii Orygenesa we współczesnym przepowiadaniu, VoxP 75 (2020) s. 139-161.

Głowacki Z., «Ordo initiationis christianae adultorum» przykładem recepcji katechumenatu wczesnochrześcijańskiego $w$ teologii liturgicznej Aidana Kanvanagha (1929-2006), VoxP 75 (2020) s. 163-184.

Kaczmarek T., W miejsce biografii, VoxP 75 (2020) s. 13-25 [przedruk z księgi jubileuszowej poświęconej ks. Tomaszowi Kaczmarkowi: „Studia Włocławskie” 12 (2009)].

Kaczmarek T., Kalendarium życia $i$ działalności ks. Tomasza Kaczmarka, VoxP 75 (2020) s. 27-30.

Kaczmarek T., Wykaz publikacji ks. Tomasza Kaczmarka, VoxP 75 (2020) s. 31-39.

List apostolski Papieża Franciszka Scripturae Sacrae affectus w XVI stulecie śmierci św. Hieronima, VoxP 76 (2020) s. 7-25.

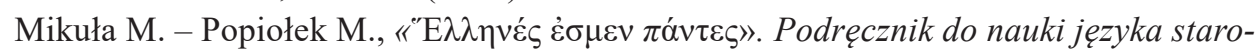
greckiego, t. 1-3, wyd. 2, Warszawa: Wydawnictwo Naukowe Sub Lupa, 2020.

Stawiszyński W., Polska bibliografia antyku chrześcijańskiego 2017-2019, VoxP 74 (2020) s. 231-306.

Szerszeń M., Wybrane publikacje $z$ dziedziny antyku $i$ tradycji antycznej wydane w latach 2018-2019, „Nowy Filomata” 23/2 (2019) s. 173-181.

Szuppe P., Bibliografia publikacji ks. prof. dr. hab. Waldemara Chrostowskiego w "Collectanea Theologica» (1990-2020), CT 90/2 (2020) s. 259-290.

Szram M., Prace dyplomowe napisane pod kierunkiem ks. prof. dr. hab. Jerzego Patuckiego, w: Nullum referenda gratia maius est officium. Ksiegga jubileuszowa dedykowana Księdzu Profesorowi Jerzemu Pałuckiemu z okazji 65-lecia urodzin i 30-lecia pracy naukowej, red. M. Szram - M. Wysocki, Lublin: Wydawnictwo KUL, 2020, s. 41-44.

Szram M. - Wysocki M., Ks. prof. dr hab. Jerzy Pałucki - życie i działalność naukowo-organizacyjna, w: Nullum referenda gratia maius est officium. Księga jubileuszowa dedykowana Księdzu Profesorowi Jerzemu Pałuckiemu z okazji 65-lecia urodzin i 30-lecia pracy naukowej, red. M. Szram - M. Wysocki, Lublin: Wydawnictwo KUL, 2020, s. 23-30.

Wysocki M., Wykaz prac dyplomowych z antyku chrześcijańskiego ukończonych w polskich ośrodkach naukowych w latach 2015-2019, VoxP 74 (2020) s. 221-230.

Wysocki M., Wykaz publikacji ks. prof. dr. hab. Jerzego Pałuckiego, w: Nullum referenda gratia maius est officium. Ksiega Jubileuszowa dedykowana Księdzu Profesorowi Jerzemu Pałuckiemu z okazji 65-lecia urodzin i 30-lecia pracy naukowej, red. M. Szram - M. Wysocki, Lublin: Wydawnictwo KUL, 2020, s. 31-39. 


\section{Prace ogólne, historie literatury}

Artemiuk P., Sokrates $i$ nowa apologia, „Studia Teologiczne Białystok-Drohiczyn-Łomża" 38 (2020) s. 33-53.

Chrost S., Ojcowie Kościoła a pedagogika. Studium antropologiczne, Warszawa: Difin, 2018.

Gilson É, Metamorfozy Państwa Bożego, Warszawa: Teologia Polityczna, 2020.

Kamczyk W., Bogowie i demony. Augustyn z Hippony i religijność pogańska późnej starożytności, SACh SN 22, Katowice 2020.

Leśniakiewicz-Drzymała R., Mitologia północy. Funkcjonowanie wybranych elementów przedchrześcijańskich mitów w średniowiecznej kulturze chrześcijańskiej $w$ świetle źródeł skandynawskich i anglosaskich, Kraków: Wydawnictwo Avalon, 2020.

Maqueo D., The Vice of Lust and its Impact on Intellectual Knowledge in the Teachings of Some Fathers of the Church, BPTh 13/3 (2020) s. 341-355.

Metzdorf J., Bóg stwarza przestrzeń. Spojrzenie z ojcami Kościoła na ostatnia prośbe «Ojcze nasz», „Communio” 40/209 (2020) s. 108-117.

Niesiołowski-Spano Ł., Tożsamości Judejczyków okresu Drugiej Świątyni i relacje z obcymi, „Rocznik Teologiczny” 62/1 (2020) s. 7-23.

Pilarczyk K., W poszukiwaniu źródet do historii całunu Jezusa. Rekonesans po piśmiennictwie chrześcijańskiego antyku i średniowiecza, BPTh 13/3 (2020) s. 291-323.

Pytel J., Pojęcie gościnności w literaturze biblijnej i greckiej, „Życie konsekrowane” 2 (2019) s. 14-25.

Kochanek P., Map of Albi as a Geopolitical Cryptogram. A Proposal for a New Interpretation, „Res Historica” 49 (2020) s. 11-30.

Szczur P., Kradzież w dobie późnego Cesarstwa Rzymskiego a wczesne chrześcijaństwo. Od Septymiusza Sewera do Grzegorza I Wielkiego, Lublin: Wydawnictwo KUL, 2020.

Witowski W., Kościót wobec stużby wojskowej $i$ wojny $w$ świetle wybranych kanonów ksiag pokutnychod VI do XI wieku, „Littera Antiqua” 14 (2019) s. 57-71. (wyd. internetowe).

Wojtczak-Szyszkowski J., De Hieronymo Stridoninsi stilum et linguam antiquorum auctorum in epistulis secuto (epistulae et problemata selecta), VoxP 76 (2020) s. $157-167$.

Wysocki M., Itineribus Ecclesiae. Ojcowie Kościoła mistrzami zrozumienia dziejów Kościoła, w: Kościót na drogach przeszłości, red. J. Walkusz - M. Nabożny, Lublin: Wydawnictwo KUL, 2020, s. 379-388. 


\section{Historia wspólnot, instytucji, okresów historycznych, regionów}

Bralewski S., Empress Eudoxia in the Light of the 5th-Century Ecclesiastical Histories, VoxP 75 (2020) s. 43-65.

Chudzikowska-Wołoszyn M., Status oraz tradycje wychowawcze frankońskich matres familias - na przykładzie Herchenefredy (VII w.) oraz Dhuody z Septymanii (ok. 803-843), VoxP 73 (2020) s. 149-178.

Dębiński A., Polityka ustawodawcza rzymskich cesarzy chrześcijańskich $w$ sprawach religijnych, Lublin: Wydawnictwo KUL, 2020.

Dobrzyński A., Synodalność Kościoła niepodzielonego, Tarnów: Wydawnictwo Biblos, 2020.

Dusik-Krupa E., Uniwersalizm kanonów synodu w Gangrze (340 r.), „Rocznik Teologiczny" 62/1 (2020) s. 87-108.

Izdebski A., Biskupi i mnisi w Kościele Wschodu pod panowaniem Sasanidów, „U Schyłku Starożytności. Studia Źródłoznawcze” 17/18 (2018/2019) s. 171-196.

Jędrzejewska D., Chrystianizacja i romanizacja elit $w$ rzymskiej Edessie, VoxP 73 (2020) s. 25-48.

Kasprzak D., Cezary z Arles wobec «paenitentia secunda» w VI wieku, „Polonia Sacra” 24/4 (2020) s. 5-23.

Kasprzak D., Praktyki postne $w$ wybranych relacjach pisarzy kościelnych greckich i tacińskich I-III wieku, VoxP 74 (2020) s. 7-28.

Kołosowski T., Celibat duchownych - normy prawne, jego motywacje i praktyka w Kościele galijskim od połowy IV do połowy VI w. w świetle kanonów synodów kościelnych, VoxP 75 (2020) s. 285-297.

Kubisiak P., Historia kary krzyżowej w czasach starożytnych, WST 33/1 (2020) s. 256-273.

Kuźma A., Autorytet Kościoła rzymskiego i jego biskupa w nauczaniu św. Ireneusza z Lyonu, Tertuliana i św. Cypriana z Kartaginy, „Rocznik Teologiczny” 62/4 (2020) s. 1151-1191.

Misiarczyk L., Gdzie leżat starożytny Strydon? Przegląd najważniejszych hipotez jego lokalizacji, VoxP 76 (2020) s. 29-48.

Misiarczyk L., Status Żydów w Cesarstwie chrześcijańskim wedtug Księgi XVI Kodeksu Teodozjusza - cz. II: Kary nakładane na Żydów, „Seminare” 41/3 (2020) s. 105-124.

Sadowski M., Stosunek władzy i opinii publicznej do chrześcijan w Cesarstwie Rzymskim w I-II wieku, „Studia Redemptorystowskie” 18 (2020) s. 337-353.

Selejdak R., Diaconato secondo la «Traditio» patristica, „Warszawskie Studia Pastoralne" 1 (2020) s. 7-46.

Szczur P., Odbiorcy jałmużny biskupiej w Kościele starożytnym. Zarys problematyki, w: W przestrzeni słowa i czasu. Księga jubileuszowa dla Księdza Profesora Jana Walkusza, red. T. Moskal - M. Nabożny, Lublin: Wydawnictwo KUL, 2020, s. 781-803.

Szpetkowska B.J., Zamienniki pokut w ujęciu irlandzkich i brytyjskich ksiag pokutnych, „Polonia Sacra” 24/1 (2020) s. 113-134. 
Szram M., Cnota pokory a postawa ubóstwa w rozumieniu greckich Ojców Kościoła IV wieku, w: Nullum referenda gratia maius est officium. Ksiega jubileuszowa dedykowana Księdzu Profesorowi Jerzemu Pałuckiemu z okazji 65-lecia urodzin i 30-lecia pracy naukowej, red. M. Szram - M. Wysocki, Lublin: Wydawnictwo KUL, 2020, s. 349-354.

Szram. M., Jakie ciało nie osiąnie królestwa Bożego? Patrystyczna egzegeza 1 Kor 15, 50, BibAn 10/1 (2020) s. 103-114.

Widok N., Warunki dobrego postu wedtug wybranych pisarzy greckich IV-V wieku, VoxP 74 (2020) s. 119-143.

Wilczyński M., Heretycki szał czy recepcja cesarskiego prawodawstwa $w$ polityce religijnej królów wandalskich? "Codex Theodosianus» XVI a «Edictum Hunirici», VoxP 75 (2020) s. 527-538.

Wojcieszak M., Znaczenie pielgrzymek dla chrześcijan epoki późnego antyku w relacji św. Paulina z Noli (354/355-431), SPelpl 54 (2020) s. 329-343.

\section{Historia doktryn (teologia i filozofia)}

Czyżewski B., Aksjomat 'extra ecclesiam nulla salus' w starożytności chrześcijańskiej, „Przegląd Religioznawczy” 4 (2020) s. 93-103.

Drygier M., Źródło usprawiedliwienia w świetle «Homilii na List św. Pawła do Rzymian» Jana Chryzostoma, VoxP 75 (2020) s. 121-138.

Gilski M., Argumentacja Soboru Nicejskiego II za kultem ikon, SSan 26 (2019) s. 213-225.

Gołaszewska K., Logos, Wcielenie i Bóstwo Jezusa w dyskursie Orygenesa, w: Biblia i bibliodrama $w$ nowej ewangelizacji, red. M. Kowalczyk - B. Chrudzimska, Warszawa: Wydawnictwo Naukowe UKSW, 2020, s. 49-68.

Karczewski Ł., Islam $w$ «De haeresibus» Jana z Damaszku. Analiza źródłoznawczawybrane zagadnienia, VoxP 75 (2020) s. 229-266.

Kinchyk O., Sakrament posłania. Teologia sakramentu Ducha Świętego w Kościołach chrześcijańskich, Kraków: Wydawnictwo „scriptum”, 2020.

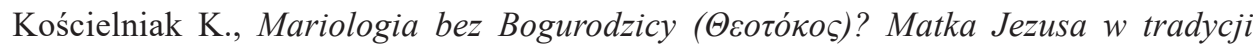
wschodniosyriackiej (nastoriańskiej) starożytnego Kościoła Wschodu, w: Kościót i Maryja, red. A.A. Napiórkowski, A. Śledzikowska, Cracoviensis Cogitatio Ecclesialis 11, Kraków: Wydawnictwo UPJPII / Salwator, 2020, s. 69-90.

Kowalski M., Między darem Bożym a konstruktem społecznym. Wczesnochrześcijańskie rozumienie płciowości na podstawie 1 Kor 11,2-16, BPTh 13/1 (2020) s. 59-104.

Mejzner M., Boski Logos: od Osoby do księgi, w: Biblia i bibliodrama w nowej ewangelizacji, red. M. Kowalczyk - B. Chrudzimska, Warszawa: Wydawnictwo Naukowe UKSW, 2020, s. 41-47.

Mejzner M., Teologia stworzenia w świetle wczesnochrześcijańskiego millenaryzmu, „Communio” 39/4 (2019) s. 45-71. 
Nieścior L., Dziewictwo Maryi i łacińska recepcja ideału dziewicy ,świętej i ciałem, i duchem" (1 Kor 7,34), w: Maryja w Biblii i refleksji Ojców Kościoła [1], s. 113-128.

Paczkowski M., Krytyka millenarystycznego obrazu Jerozolimy u św. Hieronima ze Strydonu, VoxP 75 (2020) s. 345-373.

Płotka M., Czy przedmiotem radości może być coś innego niż Bóg? Augustyn, Piotr Lombard, Bonawentura o «usus» $i$ «fruitio», SPCh 3 (2019) s. 5-32.

Sienkiewicz E., Eschatologia w pismach św. Hieronima, w: Święty Hieronim: egzegeta, dogmatyk, polemista [1], s. 65-92.

Soprych J., Temat Maryi na soborach powszechnych, w: Maryja w Biblii i Kościele [1], s. 457-468.

Spychała D., Anomeizm (arianizm, neoarianizm, eunomianizm) na zachodzie Imperium Rzymskiego od zaistnienia do IV w. po Chr. Problem teologiczny i filozoficzny, Bydgoszcz: Wydawnictwo Uniwersytetu Kazimierza Wielkiego, 2020.

Szczur P., Ojcowie greccy o Maryi i Jej roli w historii zbawienia, w: Kościót i Maryja, red. A.A. Napiórkowski, A. Śledzikowska, Cracoviensis Cogitatio Ecclesialis 11, Kraków: Wydawnictwo UPJPII / Salwator, 2020, s. 50-68.

Szymczak T., Rydwan, Okręt, Gołębica - Maryja Matka życia w myśli syryjskich Ojców Kościoła, w: Maryja Matka życia, red. G.M. Bartosik - I. Klimczyk - I. Krysiak, Warszawa: Wydawnictwo Naukowe UKSW, 2020, s. 29-48.

Turzyński P., Zasada wewnętrzności w myśli świętego Augustyna, VoxP 75 (2020) s. 485-506.

Uciecha A., Teologia postu w „Hymnach o poście” św. Efrema Syryjczyka, VoxP 74 (2020) s. 49-65.

Żurek A., Mariologia wczesnochrześcijańska, w: Maryja w Biblii i Kościele [1], s. 427-439.

Żurek A., Maryjna pobożność w czasach ojców Kościoła, w: Maryja w Biblii i Kościele [1] s. 441-453.

\section{Liturgia}

Bartocha W., Nałożenie rąk $w$ liturgii święceń $w$ pierwszym tysiacleciu (Część I: Starożytność chrześcijańska), RT 66/8 (2019) s. 5-22.

Bartocha W., Nałożenie rąk $w$ liturgii święceń $w$ pierwszym tysiącleciu (Część II: Średniowiecze), RT 67/8 (2020) s. 5-24.

Grajewski Cz., «Gratulemur in honore» - endemiczne oficjum o św. Katarzynie Aleksandryjskiej, ,Seminare” 41/1 (2020) s. 103-117.

Grzywa A., Symbolika szaty w starożytnych obrzędach katechumenalnych i chrzcielnych, BPTh 13/3 (2020) s. 277-289.

Kinchyk O., Sakrament posłania. Teologia sakramentu Ducha Świętego w Kościołach chrześcijańskich, Kraków: Wydawnictwo „scrtiptum”, 2020. 
Moskal T., U źródel liturgii. Liturgika a historia Kościoła, „Studia Liturgiczne” 15 (2019) s. 47-58.

Pałęcki W., «W swoim Kościele Pan otworzyt jego usta» (por. Syr 15, 5). Orędownictwo św. Jana Apostoła i Ewangelisty w świetle formularzy mszalnych Kościoła zachodniego do Soboru Trydenckiego, RT 67/8 (2020) s. 39-57.

Potoczny M.R., Matzeństwo w Asyryjskim Kościele Wschodu. Studium systematyczne z odniesieniami do innych tradycji chrześcijańskiego Orientu, RT 67/8 (2020) s. 59-74.

Wygralak P., Miejsce liturgii w refleksji Ojców Kościoła, „Studia Liturgiczne” 15 (2019) s. 29-46.

Żurek A., Inicjacja chrześcijańska w świetle kazań Cezarego z Arles, „Polonia Sacra” 24/4 (2020) s. 43-60.

\section{Hagiografia, monastycyzm, historia duchowości}

Czyżewski B., Zadania opata określone w prawodawstwie monastycznym kręu św. Fruktuoza z Bragi, VoxP 75 (2020) s. 67-87.

Degórski B., Le fonti e le tematiche teologiche della «Regula» di Eugippio, VoxP 75 (2020) s. 89-120.

Kamczyk W., «Żywot świętego Awita, biskupa Vienne»w świetle jego korespondencji, ŚSHT 53/1 (2020) s. 49-62.

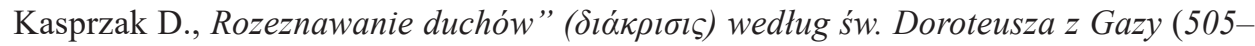
560/580), „Polonia Sacra” 24/3 (2020) s. 111-126.

Klimas S., Samotność w teologii pustyni, „Życie konsekrowane” 3 (2019) s. 31-55.

Nocoń A., Kult świętych w piśmie Hieronima „Przeciw Wigilancjuszowi”. Kwestia współczesnych tłumaczeń, VoxP 76 (2020) s. 87-105.

Starowieyski M., Czego moga nas nauczyć Ojcowie Pustyni?, wyd. 2, Kraków: Wydawnictwo Petrus, 2020.

Synowiec D., Samotność życia pustelniczego, „Życie konsekrowane” 3 (2019) s. 10-30.

Turek W., Dziewictwo rozumiane jako ustawiczna walka dla Pana: fundamenty biblijne w „Liście 22”św. Hieronima do Eustochium, VoxP 76 (2020) s. 107-129.

Wojtczak M., Between Heaven and Earth: Family ownership versus rights of monastic communities. ,, The Theodosian Code” and late antique legal practice, „U Schyłku Starożytności. Studia Źródłoznawcze” 17/18 (2018/2019) s. 117-170.

Zmorzyński Z., Gościnność Ojców Pustyni, „Życie konsekrowane” 2 (2019) s. 26-39. 


\section{Archeologia i historia sztuki}

Chrzanovski L., Lampes antiques, byzantines et islamiques du Nil à l'Oronte. La Collection Bouvier, Warszawa: Wydawnictwo UW, 2020.

Cybulski P., Библейское повествование o потопе в контексте древних ближневосточных памятников, „Elpis” 22 (2020) s. 87-90.

Góźdź Sz., Recepcja i swoistość. Butgarskie malarstwo ikonowe od IX do XII wieku, „Studia Redemptorystowskie” 18 (2020) s. 279-293.

Mordechai L., Berytus and the aftermath of the 551 earthquake, „U Schyłku Starożytności. Studia Źródłoznawcze" 17/18 (2018/2019) s. 197-241.

Nowiński J., „Ecclesia est paradisus” - interpretacja Kościoła jako raju na „Planie z Sankt Gallen” z 819 r., ,Seminare” 41/2 (2020) s. 127-135.

\section{Biblia}

Bardski K., Duch Święty jako żywioły natury w symbolicznych interpretacjach Starego Testamentu w tradycji łacińskiej, „Verbum Vitae” 37/1 (2020) s. 185-199.

Bardski K., Święty Hieronim jako ttumacz Biblii, czyli krzew nad głowa Jonasza (Jon 4,6), w: Święty Hieronim: egzegeta, dogmatyk, polemista ..., red. P. Wygralak, Teologia Patrystyczna 16, Poznań: Wydział Teologiczny UAM, 2019, s. 51-63.

Bąk T.B., A Critical Edition and Philological Analysis of the Text of Isa 44:6-45:25 Based on the Coptic Manuscript sa 52 (M 568), Other Manuscripts Written in the Sahidic Coptic Dialect, and on the Greek Text of the Septuagint, "Verbum Vitae” 38/2 (2020) s. 529-563.

Czyżewski B., Ojcowie Kościoła o Piśmie Świętym, Poznań: Uniwersytet im. Adama Mickiewicza, 2020.

Jutkiewicz P., Między tłumaczeniem słów a tłumaczeniem sensu. Współczesne spojrzenie na historię syryjskich przekładów Nowego Testamentu na przykładzie J 3,1.2.16.17, BibAn 10/3 (2020) s. 457-473.

Królikowski J., Geneza „, dwóch Testamentów” Pisma Świętego, VoxP 73 (2020) s. 7-23.

Nieścior L., Symbolika namaszczenia głowy i obmycia twarzy przez poszczacego (Mt 6,17) w interpretacji patrystycznej, VoxP 74 (2020) s. 29-48.

Paczkowski M., Łk 14, 2-4 w egzegezie patrystycznej, BPTh 13/4 (2020) s. 421-449.

Sołomieniuk M., Świętego Hieronima przedmowy do ksiag biblijnych $w$ Wulgacie zagadnienia wstepne, VoxP 76 (2020) s. 67-86.

Strzałkowska B., Księga Abdiasza w Septuagincie, CT 90/1 (2020) s. 19-76.

Szram M., Ślady wczesnochrześcijańskiej egzegezy aleksandryjskiej $w$ tacińskiej interpretacji Starego Testamentu, w: W przestrzeni słowa i czasu. Księga jubile- 
uszowa dla Księdza Profesora Jana Walkusza, red. T. Moskal - M. Nabożny, Lublin: Wydawnictwo KUL, 2020, s. 805-820.

Szram. M., Jakie ciało nie osiagnie królestwa Bożego? Patrystyczna egzegeza 1 Kor 15, 50, BibAn 10/1 (2020) s. 103-114.

Tronina A., Komentarze biblijne z Qumran. Od midraszu do peszeru, Kraków-Mogilany: The Enigma Press, 2020.

Wygralak P., ,Blessed are the pure in heart, for they shall see God” (Mt 5:8) as Interpreted by the Church Fathers (4th-5th cent.), „Verbum Vitae” 38/2 (2020) s. 579-591.

\subsection{Apokryfy}

Apokryfy Nowego Testamentu, t. 1, część 1 i 2: Ewangelie apokryficzne, red. M. Starowieyski, wyd. 3, Kraków: Wydawnictwo WAM, 2020.

Apokryfy Nowego Testamentu, t. 2, część 1 i 2: Apostołowie, red. M. Starowieyski, wyd. 3, Kraków: Wydawnictwo WAM, 2020.

Apokryfy Nowego Testamentu, t. 3: Listy i apokalipsy chrześcijańskie. Apokryfy syryjskie, red. M. Starowieyski, wyd. 3, Kraków: Wydawnictwo WAM, 2020.

Dec P., Hymny Dziękczynne z Qumran, opr. A. Tronina, Kraków-Mogilany: The Enigma Press, 2020.

Pilarczyk K., W poszukiwaniu źródet do historii catunu Jezusa. Rekonesans po piśmiennictwie chrześcijańskiego antyku i średniowiecza, BPTh 13/3 (2020) 291-323.

Stelmach W., „,Historyja barzo cudna” wobec źródet. Przekład, kompilacja, dzieło, Lublin: Wydawnictwo KUL, 2020.

Tronina A., ,Idealny” kalendarz w Księdze Jubileuszy, „Verbum Vitae” 38/1 (2020) s. 63-78.

Wróbel M., The Eschatological Spirituality of ,, the Sons of Light” in Qumran, „Verbum Vitae" 37/2 (2020) s. 347-363.

Wygralak P., Duchowa sylwetka Maryi w Apokryfach Nowego Testamentu, w: Maryja w Biblii i refleksji Ojców Kościoła [1], s. 65-78.

\subsection{Gnostycyzm}

-, Ewangelia Filipa (NHC II, 3), opr. P. Kieniewicz, b.m.w.: Wydawnictwo Nearche, 2020.

Dobkowski M., The figure of Sethel in the Medinet Madi Manichaean Writings: A result of the influence of the Gnostic Sethianism? Observations on Manichaeism as a religious system, „U Schyłku Starożytności. Studia Źródłoznawcze” 17/18 (2018/2019) s. 39-60.

Myszor W., Selected Studies on Gnosticism, SACH SN 23, Katowice: Księgarnia św. Jacka, 2020. 
Piwowarczyk P., Demonologia jako źródło do badań nad pochodzeniem i przeznaczeniem tekstów i kodeksów z Nag Hammadi, „U Schyłku Starożytności. Studia Źródłoznawcze” 17/18 (2018/2019) s. 3-38.

Piwowarczyk P., Modlitwa do emanacji, czyli manichejska modlitwa codzienna z Kellis (P. KellisGr. 98), ŚSHT 3/1 (2020) s. 36-48.

Piwowarczyk P., Obcy (Allogenes). Czwarty utwór z Kodeksu Tchacos: wstęp, przekład komentarz, ŚSHT 2/1 (2019) s. 23-37.

Sowińska A., ,Fragmenta” $i$,,testimonia” hermetyczne u autorów różnych. Wstępny przegląd źródet, VoxP 75 (2020) s. 473-484.

Sowińska A., List Piotra do Filipa z kodeksu Tchacos - tekst i wprowadzajacy komentarz filologiczny, ŚSHT 52/1 (2019) s. 38-48.

Sowińska A., Magnum miraculum est homo... The Phenomenon of Man in the Light of Hermetic Excerpts: Lactantius, Div. inst. 7.13.3, BibAn 10/4 (2020) s. 707-733.

\section{Patrystyka i średniowiecze (lacińskie i bizantyńskie)}

\subsection{Przekłady}

Bernard z Clairvaux, Apologia dla Wilhelma, opata u św. Teodoryka, tł. A. Strzelecka, w: Zasady życia w klasztorze mniszym [1], s. 64-85.

Bernard z Clairvaux, List do Roberta, krewnego, który przeszedt z zakonu cysterskiego do wspólnoty Cluny, tł. A. Strzelecka, w: Zasady życia w klasztorze mniszym [1], s. 52-61.

Hildegarda z Bingen, List do Kapituły Generalnej Cystersów, tł. A. Strzelecka, w: Zasady życia w klasztorze mniszym [1], s. 88-90.

Michał Panaretos, Kronika trapezuncka, tł. M. Cyrulski, Series Ceranea 6, Łódź: Wydawnictwo Uniwersytetu Lódzkiego, 2020.

Psellos (Pseudo-), O demonach (Timotheos albo o demonach; Poglady Hellenów na temat demonów), tł. E. Żybert, Bibliotheca Curiosa 40, Wrocław: Oficyna Wydawnicza ATUT - Wrocławskie Wydawnictwo Oświatowe, 2020.

Mistrz Eckhart, Dzieła wszystkie, t. 4: Kazania 87-117, tł. W. Szymona, Poznań: Wydawnictwo „W drodze”, 2020.

Odon z Cluny, Żywot św. Geralda z Aurillac, tł. E. Buszewicz, opr. M. Brzozowska, ŹrMon 89, Kraków: Wydawnictwo TYNIEC, 2020.

Piotr Damiani, Kazania o dziewicach, tł. E. Buszewicz, opr. K. Świerczyński, ŹrMon 91, Kraków: Wydawnictwo Benedyktynów TYNIEC, 2020.

Rudolf Glaber, Kroniki roku tysięcznego, tł. E. Buszewicz, opr. M.T. Gronowski K. Skwierczyński, ŹrMon 90, Kraków: Wydawnictwo TYNIEC, 2020.

Teodor Prodromos, Przygody Rodante i Dosyklesa, tł. M. Cyrulski, Katowice: Wydawnictwo Uniwersytetu Śląskiego, 2020. 
Tomasz z Akwinu, Dysputy o uczuciach. Dysputy problemowe o prawdzie. Kwestie 25 i 26, tł. A. Białek, Lublin: Polskie Towarzystwo Tomasza z Akwinu, 2020.

\subsection{Opracowania}

Brzozowska Z.A. - Leszka M.J. - Marinow K. - Wolińska T., Widmo Mahometa. Cień Samuela. Cesarstwo bizantyjskie $w$ relacji z przedstawicielami innych religii $i$ kultur (VII-XVw.), Byzantina Lodziensia 39, Łódź: Wydawnictwo Uniwersytetu Łódzkiego, 2020.

Dahan G., Intelektualiści chrześcijańscy wobec Żydów w średniowieczu, Kęty: Wydawnictwo Marek Derewiecki, 2020.

Gies F. - Gies J., Życie średniowiecznej rodziny, Kraków: Wydawnictwo Znak, 2020.

Goff Le-, J., Czas uświęcony. Jakub de Voragine i „Złota legenda”, tł. B. Szczepańska J. Nowacki, Warszawa: Wydawnictwo Volumen (seria Marianna), 2020.

Grzesik T., Średniowieczna myśl filozoficzna jako obrona przed dekonstrukcja filozofii współczesnej, ŚSHT 52/2 (2019) s. 249-265.

Mühle E., Słowianie. Rzeczywistość i fikcja wspólnoty, VI-XV wiek, Warszawa: Wydawnictwo PWN, 2020.

Paroń A., „Daremnie próbuje się wybielić Etiopa” - postrzeganie i polityka Bizancjum wobec koczowników stepów czarnomorskich (X-XII w.), VoxP 75 (2020) s. 375-413.

Piazzoni A.M, Wilhelm z Saint-Thierry. Schyłek ideału monastycznego $w$ XII wieku?, tł. I. Rogusz, red. M.T. Gronowski, Źródła Monastyczne Monografie 8, Kraków: Wydawnictwo TYNIEC, 2020.

Rzeźnicka Z. - Kokoszko M., Milk and Dairy Products in the Medicine and Culinary Art of Antiquity and Early Byzantium (1st-7th Centuries AD), Byzantina Lodziensia 38, Łódź: Wydawnictwo Uniwersytetu Łódzkiego, 2020.

Sińczak T., Ostatni szach. Obraz Chosroesa II Parweza (591-628), króla Iranu, w krótkiej kronice końca sasanidzkiego imperium i wczesnego Iranu, Toruń: Marszałek Development \& Press, 2020.

Skibiński T., Kształtowanie się obrazu Gepidów w źródłach antycznych $i$ wczesnośredniowiecznych (III-VII w.), VoxP 75 (2020) s. 453-471.

Strzelczyk J. - Strzelczyk A., Święci władcy Europy, Częstochowa: Uniwersytet Humanistyczno-Przyrodniczy im. Jana Długosza, 2020.

\section{Autorzy}

\section{Afrahat}

-, Mowa XVII - O Chrystusie, Synu Bożym (Demonstratio XVII: De Christo Dei Filio), PSyr 1, 785-816, tł. A. Uciecha, VoxP 73 (2020) s. 181-197. 
-, Mowa XIX - Przeciwko Żydom, którzy mówia, że na nowo zostana zgromadzeni (Demonstratio XIX: Adversus Iudaeos qui dicunt se denuo congregatum iri), PSyr 1, 845-892, tł. A. Uciecha, VoxP 75 (2020) s. 605-629.

\section{Akta męczenników}

Męczeństwo Juliusza Weterana, tł. J. Kozłowski, w: Męczennicy [1], s. 356-360.

Męczeństwo św. Agape, Ireny (Eirene) i Chione z Tesalonik, tł. J. Kozłowski, w: Męczennicy [1], s. 326-333.

Męczeństwo św. Dasjusza, tł. J. Kozłowski, w: Męczennicy [1], s. 334-338.

Męczeństwo św. Euplusa, tł. J. Kozłowski, w: Męczennicy [1], s. 338-340.

Męczeństwo św. Ireneusza, biskupa z Sirmium, tł. J. Kozłowski, w: Męczennicy [1], s. 340-344.

Męczeństwo św. Kryspiny, tł. J. Kozłowski, w: Męczennicy [1], s. 360-364.

Męczeństwo św. Marcellusa, tł. J. Kozłowski, w: Męczennicy [1], s. 323-326.

Męczeństwo św. Mariana i Jakuba, tł. J. Kozłowski, w: Męczennicy [1], s. 237-249.

Męczeństwo św. Montanusa i Lucjusza, tł. J. Kozłowski, w: Męczennicy [1], s. 249-263. Męczeństwo św. Karpusa, Papilusa i Agatoniki - recenzja grecka, tł. J. Kozłowski, w: Meczennicy [1], s. 128-132.

Męczeństwo św. Pioniosa i jego towarzyszy, tł. J. Kozłowski, w: Męczennicy [1], s. 200-219. Męczeństwo świętego i przestawnego Apostoła Apoloniusza [Apollosa], zwanego Sakkeasem, tł. J. Kozłowski, w: Męczennicy [1], s. 150-159.

Testament czterdziestu świętych i godnych czci męczenników Chrystusa, którzy zginęli w Sebaście, tł. J. Kozłowski, w: Męczennicy [1], s. 383-387.

Wysocki M., Dignity in Suffering: Testimonies of the Acts of Martyrdom, w: Dignity in Suffering - Closeness in Dying - Love in Mourning. Interdyscyplinary Study, red. C. Ciccarino - M. Kalinowski - K.K. Masłowski - L. Szot - A. Świerczek - D. Traflet, Lublin: Towarzystwo Naukowe KUL, 2020, s. 65-76.

\section{Akta męczenników donatystów}

Męczeństwo Izaaka i Maksymiana, tł. S. Adamiak, w: Męczennicy [1], s. 390-400.

\section{Albumasar}

-, Flores astrologie. Kwiatki astrologii, th i opr. S. Konarska-Zimnicka - B. Wojciechowska - L. Kostuch - P. Piotrowski, Kielce: Wydawnictwo Uniwersytetu Jana Kochanowskiego, 2020 (przekład z łacińskiego wydania Erharda Ratdolta, Augsburg 1488).

Konarska-Zimnicka S. - Piotrowski P., Albumasar i jego „,Ysagoga minor”, Kielce: Wydawnictwo Uniwersytetu Jana Kochanowskiego, 2020 (w aneksie przekład z łacińskiego tłumaczenia Adelarda z Bath). 


\section{Ambroży z Mediolanu}

Czyżewski B., ,,Uczyńmy człowieka na Nasz obraz, podobnego Nam” (Rdz 1,26) w interpretacji Bazylego Wielkiego i Ambrożego z Mediolanu, „Наукові записки УКУ: Богослов'я. Вип” 7 (2020) s. 319-332.

Czyżewski B., Wątki mariologiczne w Listach św. Ambrożego z Mediolanu, w: Maryja w Biblii i refleksji Ojców Kościoła [1], s. 129-145.

Mielnik D., Poprawność skrypturystycznej argumentacji Ambrożego w dziele „O tajemnicy wcielenia Pańskiego" w aspekcie filozoficzno-teologicznym, Lublin: TN KUL, 2020.

Zagórski D., Człowiek w „Expositio Evangelii secundum Lucam” św. Ambrożego z Mediolanu, BPTh 13/4 (2020) s. 451-463.

\section{Anastazy Synajski}

Piasecki D., „Mysterium mortis” w ujęciu Anastazego Synaity, VoxP 75 (2020) s. $415-429$.

\section{Annales}

-, Annales Regni Francorum. Roczniki Królestwa Franków, tł. G.K. Walkowski, Bydgoszcz: Wydawnictwo Walkowski, 2020 (także tekst łaciński).

\section{Anonim}

-, Dziełko o duszy (CPG 1773/7717: Ad Tatianum de anima per capita disputatio/Opusculum de anima), tł. K. Kochańczyk-Bonińska, VoxP 75 (2020) s. 567-589.

\section{Anonim}

-, Epitafium świętych Leandra, Izydora i Florentyny (ICERV 272: Epitaphium beati Leandri, Isidori et Florentine), tł. T. Krynicka, VoxP 75 (2020) s. 591-604.

\section{Antoni Wieli (Pseudo-)}

-, O życiu wiecznym i doczesnym (Słowo o marności świata i wskrzeszeniu umartych. Pouczenia o prawdziwej moralności i świętym życiu $w 170$ rozdziałach), tł. (z ros.) M. Jakimiuk, Hajnówka: Wydawnictwo Bratczyk, 2020. 


\section{Atanazy (Pseudo-)}

Verburgt J., ,Sicut anima rationalis et caro unus est homo: ita Deus et homo unus est Christus" A Note on Aquinas'Reading of the Pseudo-Athanasian Creed, BPTh 13/2 (2020) s. 217-228.

\section{Augustyn z Hippony}

-, O wróżbiarstwie demonów (De divinatione daemonum), tł. W. Kamczyk, w: W. Kamczyk, Bogowie i demony. Augustyn z Hippony i religijność pogańska późnej starożytności, SACh SN 22, Katowice: Księgarnia św. Jacka, s. 51-71.

-, Traktat przeciw poganom (Traktatus contra paganos), tł. W. Kamczyk, w: W. Kamczyk, Bogowie i demony. Augustyn z Hippony i religijność pogańska późnej starożytności, SACh SN 22, Katowice: Księgarnia św. Jacka, s. 72-145.

-, Wyznania, tł. S. Stabryła, Kraków: Wydawnictwo Esprit, 2020.

Bernet A., Monika. Matka św. Augustyna, Kraków: Wydawnictwo eSPe, 2020.

Bobko A., Augustine and Kant - Two Founders of Modern Thinking, „Studia z Historii Filozofii" 3 (2019) s. 27-38.

Czyżewski B., The Concept of Time in „Enarrationes in Psalmos” by Saint Augustine, „Verbum Vitae” 38/1 (2020) s. 247-262.

Kucz A.M. - Matusiak P., „Praesens de praeteritis”. Regulus jako przykład bohaterstwa w „Państwie Bożym”, „Verbum Vitae” 38/1 (2020) s. 263-280.

Płotka M., Czy przedmiotem radości może być coś innego niż Bóg? Augustyn, Piotr Lombard, Bonawentura o , usus” $i$,,fruitio”, SPCh 55/3 (2019) s. 5-32.

Sambor P., Rodzina $w$ świetle augustyńskiego nauczania o porzadku miłości, „Studia Elbląskie" 21 (2020) s. 295-307.

Simms L., The Ordination and the Exercise of the Priesthood of the Baptized in Augustine, Chrysostom, and Aquinas, BPTh 13/2 (2020) s. 199-215.

Szczepanik T.P., Rzymskie cnoty ,, virtus ” $i$, fides ” w interpretacji św. Augustyna w „De civitate Dei”, KiST 18 (2019) s. 173-183.

Tück J.H., Eklezjologiczne zadomowienie millenaryzmu przez Augustyna, „Communio” 39/4 (2019) s. 72-90.

Turzyński P., Zasada wewnętrzności w myśli świętego Augustyna, VoxP 75 (2020) s. $485-506$.

Wysocki M., Cui carni fuerit speranda inmortalitas (Aug. Ep. 140, 31). The Incarnation of Christ and the Hope of Resurrection in St Augustine's Letters, w: Nullum referenda gratia maius est officium. Księga Jubileuszowa dedykowana Księdzu Profesorowi Jerzemu Pałuckiemu z okazji 65-lecia urodzin i 30-lecia pracy naukowej, red. M. Szram - M. Wysocki, Lublin: Wydawnictwo KUL, 2020, s. 443-452. 
Wysocki M., Starożytne korepetycje z mariologii? Mariologia Paulina z Noli na kanwie Listu 50 Paulina i 149 Augustyna, w: Maryja w Biblii i refleksji Ojców Kościoła [1], s. 147-165.

\section{Auzoniusz}

-, Epigram 40 Do żony, tł. K.T. Witczak, „Nowy Filomata” 24/1 (2020) s. 64 (także tekst łaciński).

\section{Awit z Vienne}

Kamczyk W., „Żywot świętego Awita, biskupa Vienne” w świetle jego korespondencji, ŚSHT 53/1 (2020) s. 49-62.

\section{Bazyli Wielki}

Budzanowska-Weglenda D., Mowy o poście Bazylego Wielkiego w łacińskiej wersji Rufina z Akwilei, VoxP 74 (2020) s. 67-91.

Czyżewski B., ,Uczyńmy człowieka na Nasz obraz, podobnego Nam” (Rdz 1,26) w interpretacji Bazylego Wielkiego i Ambrożego z Mediolanu, „Наукові записки УКУ: Богослов’я. Вип” 7 (2020) s. 319-332.

\section{Beda Czcigodny}

-, Dzieje Kościoła Anglów, tł. i opr. I. Salamonowicz-Górska, PSP 74, Warszawa: Wydawnictwo Naukowe UKSW, 2020.

Sprutta J. - Kołodziejczyk D., Beda Czcigodny - życie i twórczość. Zarys historyczny, SG 33 (2019) s. 191-210.

Sztuk D., Interpretative peculirities of the „Commentary on the Acts of the Apostles” by Bede the Venerable, „Seminare” 41/4 (2020) s. 13-21.

\section{Benedykt z Nursji}

Hiżycki Sz., Cywilizacja psałterza. Studia nad Reguła św. Benedykta, Kraków: Wydawnictwo TYNIEC, 2020. 


\section{Bertariusz z Cassinum}

-, Wiersz opata Bertariusza o cudach świętego ojca Benedykta [Versus domni Bertharii abbatis de miraculis almi patris Benedicti (PL 126, 979-98)], tł. T. Gacia, VoxP 75 (2020) s. 555-565.

\section{Boecjusz}

Torrijos-Castrillejo D., Divine foreknowledge and providence in the commentaries of Boethius and Aquinas on the „De interpretatione” 9 by Aristotle, BPTh 13/2 (2020) s. 151-173.

\section{Centony}

-, De Ecclesia, tł. M. Piatek, VoxP 75 (2020) s. 448-451 (jako aneks do artykułu: „De Ecclesia" - centon chrześcijański).

Piątek M., „De Ecclesia” - centon chrześcijański, VoxP 75 (2020) s. 431-451.

\section{Cezary z Arles}

-, Kazania o Piśmie Świętym, część I: (81-105), tł. i red. J. Pochwat, ŹrMon 88, Kraków: Wydawnictwo TYNIEC, 2020.

Modlitewnikśw. Cezarego, opr. C. Ruzik, Warszawa: Wydawnictwo Salezjańskie, 2020. Gilski M., Mariologia św. Cezarego z Arles, „Polonia Sacra” 24/4 (2020) s. 61-73.

Kasprzak D., Cezary z Arles wobec „,paenitentia secunda” w VI wieku, „Polonia Sacra” 24/4 (2020) s. 5-23.

Paczkowski M., Postać Jozuego w interpretacji Cezarego z Arles, „Polonia Sacra” 24/4 (2020) s. 75-101.

Pochwat J., Chrzest w alegorycznej interpretacji Ksiag Rodzaju i Wyjścia w homiliach św. Cezarego z Arles, „Polonia Sacra” 24/4 (2020) s. 25-101.

Pochwat J., La justice de Dieu contre Satan: Commentaire du sermon au peuple XI, w: Césaire d'Arles et les cinq continents. Hérésie et miracle dans l'œuvre de Césaire d'Arles, t. 3, Venelles: Aux sources de la Provence, 2020, s. 183-189= God's Justice against Satan: Commentary on the Sermon to the people XI, s. 191-195.

Pochwat J., Wybrane aspekty z przepowiadania św. Cezarego z Arles. Czy św. Cezary $z$ Arles będzie nowym doktorem Kościoła? „Polonia Sacra” 23/4 (2019) s. 139-158.

Żurek A., Inicjacja chrześcijańska w świetle kazań Cezarego z Arles, „Polonia Sacra” 24/4 (2020) s. 43-60. 


\section{Cyprian z Cassinum}

-, Hymn o św. Benedykcie (Hymnus de S. Benedicto, inc. Aureo solis radio perennis), tł.

T. Gacia, VoxP 76 (2020) s. 185-193.

\section{Cyprian z Kartaginy}

Kuźma A., Autorytet Kościoła rzymskiego i jego biskupa w nauczaniu św. Ireneusza z Lyonu, Tertuliana i św. Cypriana z Kartaginy, „Rocznik Teologiczny” 62/4 (2020) s. 1151-1191.

Szram M., Surowość czy miłosierdzie? Postawa Cypriana z Kartaginy wobec problemów osób duchownych na podstawie jego korespondencji, „Saeculum Christianum. Pismo Historyczne" 27/2 (2020) s. 19-32.

\section{Cyryl Jerozolimski}

Widok N., Biblijne podstawy nauczania o Duchu Świętym w „Katechezach” Cyryla Jerozolimskiego, „Verbum Vitae” 37/1 (2020) s. 147-171.

\section{Dhuoda z Septymanii}

-, Podręcznik Dhuody skierowany do jej syna Wilhelma (wybór), tł. M. Chudzikowska-Wołoszyn, VoxP 73 (2020) s. 199-236.

Chudzikowska-Wołoszyn M., Status oraz tradycje wychowawcze frankońskich matres familias - na przykładzie Herchenefredy (VII w.) oraz Dhuody z Septymanii (ok. 803-843), VoxP 73 (2020) s. 149-178.

\section{Doroteusz z Gazy}

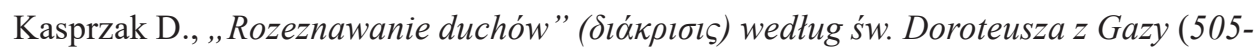
560/580), „Polonia Sacra” 24/3 (2020) s. 111-126.

\section{Dydym Ślepy}

Pancerz R.M., Miłosierdzie Boże w ujęciu Dydyma Ślepego (313-398), „Przegląd Kalwaryjski” 24 (2020) s. 127-135.

\section{Efrem Syryjczyk}

-, Hymny maryjne, tł. W. Kania, w: Syryjskie Hymny o Maryi [1], s. 53-90. 
Uciecha A., Teologia postu w „Hymnach o poście” św. Efrema Syryjczyka, VoxP 74 (2020) s. 49-65.

\section{Efrem Syryjczyk (Pseudo-)}

-, Hymny o Błogosławionej Bogarodzicy Maryi, tł. A. Bielenin, w: Syryjskie Hymny o Maryi [1], s. 91-235.

\section{Eriugena Jan Szkot}

Grzegorzyca A., Koncepcja przebóstwienia w systemie Jana Szkota Eriugeny, SPCh 55/4 (2019) s. 35-60.

Źrebiec A., Od anagogicznej pokraczności do analitycznej sztuki: Teologia symbolicz$n a w$,Expositiones in Ierarchiam Coelestem” Jana Szkota Eriugeny, „Przegląd Tomistyczny" 26 (2020) s. 121-150.

\section{Eugipiusz}

Degórski B., Le fonti e le tematiche teologiche della „Regula” di Eugippio, VoxP 75 (2020) s. 89-120.

\section{Euzebiusz z Cezarei}

-, O męczennikach palestyńskich, tł. T. Wnętrzak, w: Męczennicy [1], s. 278-315.

\section{Filokalia}

Nowa Filokalia. Droga do modlitwy serca, tł. J. Naumowicz, Kraków: Wydawnictwo Esprit, 2020.

\section{Fruktuoz z Bragi}

Czyżewski B., Zadania opata określone w prawodawstwie monastycznym kręgu św. Fruktuoza z Bragi, VoxP 75 (2020) s. 67-87. 


\section{Gnostyckie teksty}

\section{Kodeks Tchakos}

-, List Piotra do Filipa z kodeksu Tchacos - tekst i wprowadzajacy komentarz filologicz$n y$, tł. A. Sowińska, ŚSHT 52/1 (2019) s. 38-48.

-, Obcy (Allogenes). Czwarty utwór z Kodeksu Tchacos: wstęp, przekład, komentarz, tł. P. Piwowarczyk, ŚSHT 52/1 (2019) s. 23-37.

\section{Nag Hammai, biblioteka}

-, Ewangelia Filipa (NHC II, 3), opr. P. Kieniewicz, b.m.w.: Wydawnictwo Nearche, 2020.

\section{Manichejskie teksty}

-, Modlitwa do emanacji, czyli manichejska modlitwa codzienna z Kellis (P.KellisGr. 98), tł. P. Piwowarczyk, ŚSHT 53/1 (2020) s. 36-48.

\section{Grzegorz z Nazjanzu}

Dutkiewicz T., Nauka o niebie jako ostatecznym spetnieniu życia ludzkiego $w$ mowach św. Grzegorza z Nazjanzu, BPTh 13/4 (2020) s. 467-486.

Widok N., Eklezjalne cele „Pierwszej mowy o pokoju” Grzegorza z Nazjanzu, VoxP 75 (2020) s. 507-525.

Widok N., Obraz i podobieństwo Boże w myśli teologicznej św. Grzegorza z Nazjanzu, „Наукові записки УКУ: Богослов’я” 7 (2020) s. 347-357.

\section{Grzegorz z Tours}

Ludewicz M., „Zazdrośnik ten bezustannie usituje szkodzić tym, którzy szukają Boga”. Wplyw bytów demonicznych na losy jednostek i społeczności w „Historiach” Grzegorza z Tours, VoxP 75 (2020) s. 299-316.

\section{Grzegorz Wielki}

Bernet A., Papież Grzegorz Wielki. Pontyfikat w czasach zarazy, Warszawa: DeReggio, 2020. 


\section{Herchenefreda}

Chudzikowska-Wołoszyn M., Status oraz tradycje wychowawcze frankońskich matres familias - na przykladzie Herchenefredy (VII w.) oraz Dhuody z Septymanii (ok. 803-843), VoxP 73 (2020) s. 149-178.

\section{Hieronim ze Strydonu}

Bardski K., Święty Hieronim jako tlumacz Biblii, czyli krzew nad głowa Jonasza (Jon 4,6), w: Święty Hieronim: egzegeta, dogmatyk, polemista [1], s. 51-63.

Degórski B., Tipologia di donne nelle „Vitae Patrum” di san Girolamo, „Teresianum” 71/1 (2020) s. 99-120.

Degórski B., Tipologia di donne nella „, Vita S. Hilarionis” di san Girolamo, BPTh 13/1 (2020) s. 9-23.

Degórski B., Tipologia di donne nella „Vita S. Malchi monachi captivi” di san Girolamo, „Angelicum” 97 (2020) s. 213-229.

Degórski B., Tipologia di donna nella „Vita S. Pauli monachi Thebaei” di san Girolamo, VoxP 76 (2020) s. 131-142.

Degórski B., Typologia kobiety w Hieronimowych ,, Vitae Sanctorum Patrum ,, „Dissertationes Paulinorum" 29 (2020) s. 5-34.

Jóźwiak M., Hieronim ze Strydonu jako ,, vir trilinguis” na przykładzie komentarza do Iz 7,10-16, VoxP 76 (2020) s. 49-65.

Jóźwiak M., „Ni w dzień, ni w nocy nie odpoczywa; zawsze coś czyta albo pisze” (Sulp. Sev. „Dial.” 1,9,5). Słów kilka o egzegezie biblijnej św. Hieronima, w: Święty Hieronim: egzegeta, dogmatyk, polemista [1], s. 33-50.

Kieling M., ,Amicitia quae desinere potest vera nunquam fuit”. Przyjaźń w Listach św. Hieronima ze Strydonu, VoxP 75 (2020) s. 267-284.

Kieling M., Święty Hieronim ze Strydonu - humanista, egzegeta, mistrz życia duchowego, w: Święty Hieronim: egzegeta, dogmatyk, polemista [1], s. 13-31.

Nieścior L., Hieronimowa obrona postu w polemice z Jowinianem, w: Święty Hieronim: egzegeta, dogmatyk, polemista [1], s. 93-105.

Nocoń A., Kult świętych w piśmie Hieronima „Przeciw Wigilancjuszowi”. Kwestia współczesnych ttumaczeń, VoxP 76 (2020) s. 87-105.

Paczkowski M.C., Krytyka millenarystycznego obrazu Jerozolimy u św. Hieronima ze Strydonu, VoxP 75 (2020) s. 345-373.

Sielecka R., Dziewictwo najdoskonalszym wyrazem miłości do Boga na podstawie „Listów” św. Hieronima, w: Święty Hieronim: egzegeta, dogmatyk, polemista [1], s. 107-123.

Sienkiewicz E., Chrystocentryczny wymiar postu i umartwienia w pismach św. Hieronima ze Strydonu, VoxP 74 (2020) s. 93-118. 
Sienkiewicz E., Eschatologia w pismach św. Hieronima, w: Święty Hieronim: egzegeta, dogmatyk, polemista [1], s. 65-92.

Sołomieniuk M., Świętego Hieronima przedmowy do ksiag biblijnych $w$ Wulgacie - zagadnienia wstepne, VoxP 76 (2020) s. 67-86.

Turek W., Dziewictwo rozumiane jako ustawiczna walka dla Pana: fundamenty biblijne w „Liście 22” św. Hieronima do Eustochium, VoxP 76 (2020) s. 107-129.

Wojtczak-Szyszkowski J., De Hieronymo Stridoninsi stilum et linguam antiquorum auctorum in epistulis secuto (epistulae et problemata selecta), VoxP 76 (2020) s. $157-167$.

Wysocki M., The Eschatological Aspects of the Monastic Life in St. Jerome's Letters, VoxP 76 (2020) s. 143-155.

\section{Hilary z Poitiers}

Grzywaczewski J., Syn reprezentujacy Ojca $w$ „,De Trinitate” św. Hilarego z Poitiers, VoxP 75 (2020) s. 185-199.

\section{Ildefons z Toledo}

Wygralak P., Duch Święty w nauczaniu św. Ildefonsa z Toledo, VoxP 75 (2020) s. 539-552.

\section{Ireneusz z Lyonu}

Kuźma A., Autorytet Kościoła rzymskiego i jego biskupa $w$ nauczaniu św. Ireneusza z Lyonu, Tertuliana i św. Cypriana z Kartaginy, „Rocznik Teologiczny” 62/4 (2020) s. 1151-1191.

Smith R.B., Thomas Aquinas and Irenaeus on the Divine and Natural Law, BPTh 13/2 (2020) s. 175-187.

\section{Izydor Sewilli}

Wojciechowski L., Wspólne cechy zwierząt i ludzi w dwunastej księdze „Etymologii” Izydora z Sewilli, VoxP 73 (2020) s. 63-94.

Krynicka T., Izydora z Sewilli „, O narodzinach i śmierci świętych ojców”: kompendium biblijnej wiedzy oraz wademekum postepowania chrześcijanina, „Biografistyka Pedagogiczna" 5/1 (2020) s. 95-109.

Krynicka T., Izydora z Sewilli „, O narodzinach i śmierci świętych ojców”: kompozycja traktatu, VoxP 73 (2020) s. 95-121. 


\section{Jakub z Sarug}

-, Pieśń 1 o Błogosławionej Dziewicy Bogarodzicy Maryi, tł. W. Kania, w: Syryjskie Hymny o Maryi [1], s. 237-257.

\section{Jan Chryzostom}

-, Homilie na Pierwszy List Św. Pawła do Koryntian, łł. A. Paciorek. Biblia Ojców 2, Częstochowa: Edycja św. Pawła, 2020.

Baron A., Miłosierdzie w homiliach św. Jana Chryzostoma na Ewangelię wedtug św. Mateusza, „Polonia Sacra” 24/1 (2020) s. 67-86.

Drygier M., Źródło usprawiedliwienia w świetle „Homilii na List św. Pawła do Rzymian” Jana Chryzostoma, VoxP 75 (2020) s. 121-138.

Simms L., The Ordination and the Exercise of the Priesthood of the Baptized in Augustine, Chrysostom, and Aquinas, BPTh 13/2 (2020) s. 199-215.

\section{Jan Chryzostom (Pseudo-)}

Dżwigała K.M., The Woman with the Flow of Blood in the Homily of Pseudo-Chrysostom and the Kontakion of Romanos the Melodist, ,Verbum Vitae” 38/2 (2020) s. 633-648.

\section{Jan Damasceński}

Karczewski Ł., Islam w „,De haeresibus” Jana z Damaszku. Analiza źródłoznawczawybrane zagadnienia, VoxP 75 (2020) s. 229-266.

Petridou L. - Terezis Ch., Aeon as an Expression of Metaphysics of Transcendence and Metaphysics of Immanence in John Damascene, VoxP 73 (2020) s. 123-147.

\section{Jan Diakrinomenos}

-, Historia Kościoła Teodora Lektora i Jana Diakrinomenosa, tł. R. Kosiński A. Szopa - K. Twardowska, Kraków: Towarzystwo Wydawnicze „Historia Iagellonica", 2020.

\section{Jan Filiponos/Gramatyk}

Mielnik D., Filozoficzna apologia monofizytyzmu w „, Rozjemcy” Jana Gramatyka, VoxP 73 (2020) s. 49-62. 


\section{Jan Samotnik z Apamei}

-, O modlitwie, t1. T. Szymczak, VoxP 74 (2020) s. 147-155.

\section{Juniliusz Afrykańczyk}

Czyżewski B., Pneumatologia w isagodze Juniliusza Afrykańczyka, „Verbum Vitae” 37/1 (2020) s. 173-184.

\section{Kanony Atanazego}

Wipszycka E., A certain bishop and a certain diocese in Egypt at the turn of the fourth and fifth centuries: The testimony of the „, Canons of Athanasius”, „U Schyłku Starożytności. Studia Źródłoznawcze" 17/18 (2018/2019) s. 91-115.

\section{Kasja Zakonnica}

-, Strofy do śpiewania na osobne melodie, tł. A. Heszen, „Meander” 75 (2020) s. 47-50. Heszen A., Nierządnice, szaleńcy i święci. ,Exempla” w troparionach Kasji, „Meander" 75 (2020) s. 37-46.

\section{Kodeks Teodozjusza}

Wojtczak M., Between Heaven and Earth: Family ownership versus rights of monastic communities. , The Theodosian Code” and late antique legal practice, „U Schyłku Starożytności. Studia Źródłoznawcze” 17/18 (2018/2019) s. 117-170.

\section{Makary Egipski}

Białous M., Św. Makary, egipski „,Doktor Łaski”, Hajnówka: Wydawnictwo Bratczyk, 2020.

\section{Maksym Wyznawea}

Hupalo M., Motion of Human Nature towards ,,Imago Dei” in the Thought of St. Maximus the Confessor, VoxP 75 (2020) s. 201-228.

\section{Orygenes}

Bednarek T., Alegoryczna interpretacja historii Abrahama. Analiza III, IV $i$ VI „, Homilii o Księdze Rodzaju” Orygenesa, BPTh 13/3 (2020) s. 263-276. 
Duda J., ,,Grzech Maryi” w nauczaniu Orygenesa, w: Maryja w Biblii i refleksji Ojców Kościoła [1], s. 79-94.

Dyk S., Aktualność homilii Orygenesa we współczesnym przepowiadaniu, VoxP 75 (2020) s. 139-161.

Gołaszewska K., Logos, Wcielenie i Bóstwo Jezusa w dyskursie Orygenesa, w: Biblia i bibliodrama $w$ nowej ewangelizacji, red. M. Kowalczyk - B. Chrudzimska, Warszawa: Wydawnictwo Naukowe UKSW, 2020, s. 49-68.

Kieling M., Macierzyństwo i dziewictwo Maryi w „Homiliach o Ewangelii św. Lukasza” $i$,Komentarzu do Ewangelii wedtug Mateusza” Orygenesa, w: Maryja w Biblii i refleksji Ojców Kościoła [1], s. 95-112.

Szram M., Origen's Castration - Solely A Spiritual Phenomenon? An Attempt of Reinterpreting the Sources, „Gregorianum” 101/1 (2020) s. 23-36.

Zieliński J., Radość męczeństwa i realizacja Bożej Mądrości wedtug Orygenesa, „Communio" 39/3 (2019) s. 7-30.

\section{Paulin z Akwilei}

Nowak A.S., Ira mitescat tua... Przyczynek do lektury poezji suplikacyjnej Paulina z Akwilei i Seduliusza Szkota, KiST 19 (2020) s. 47-57.

\section{Paulin z Noli}

Wojcieszak M., Znaczenie pielgrzymek dla chrześcijan epoki późnego antyku $w$ relacji św. Paulina z Noli (354/355-431), SPelpl 54 (2020) s. 329-343.

Wysocki M., Moc i rola słowa wedtug Paulina z Noli i jego listów, w: W przestrzeni słowa i czasu. Księga jubileuszowa dla Księdza Profesora Jana Walkusza, red. T. Moskal - M. Nabożny, Lublin: Wydawnictwo KUL, 2020, s. 901-910.

Wysocki M., Starożytne korepetycje z mariologii? Mariologia Paulina z Noli na kanwie Listu 50 Paulina i 149 Augustyna, w: Maryja w Biblii i refleksji Ojców Kościoła [1], s. $147-165$.

\section{Pseudo-Dionizy Areopagita}

Kutarn̆a A., Hierarchy and Likeness - Ways to Union with God in Pseudo-Dionysius and Aquinas, BPTh 13/2 (2020) s. 189-198.

\section{Roman Melodos}

-, Hymny wybrane, opr. i tł. K.M. Dźwigała, PSP 75, Warszawa: Wydawnictwo Naukowe UKSW, 2020. 
Dźwigała K.M., The Woman with the Flow of Blood in the Homily of Pseudo-Chrysostom and the Kontakion of Romanos the Melodist, „Verbum Vitae” 38/2 (2020) s. 633-648.

\section{Rufin z Akwilei}

Budzanowska-Weglenda D., Mowy o poście Bazylego Wielkiego w łacińskiej wersji Rufina z Akwilei, VoxP 74 (2020) s. 67-91.

\section{Seduliusz Szkot}

Nowak A.S., Ira mitescat tua... Przyczynek do lektury poezji suplikacyjnej Paulina z Akwilei i Seduliusza Szkota, KiST 19 (2020) s. 47-57.

\section{Szymon Garncarz/Symeon Kukaia}

-, Pieśni na Boże Narodzenie, tł. T. Szymczak, w: Maryja Matka życia, red. G.M. Bartosik - I. Klimczyk - I. Krysiak, Warszawa: Wydawnictwo Naukowe UKSW, 2020, s. $49-62$.

\section{Teodor Lektor}

-, Historia Kościoła Teodora Lektora i Jana Diakrinomenosa, tł. R. Kosiński - A. Szopa - K. Twardowska, Kraków: Towarzystwo Wydawnicze „Historia Iagellonica”, 2020.

\section{Teodoret z Cyru}

Nadobnik W., Między Platonem a Plotynem. Wątki erotyczne w „Dziejach miłości Bożej” Teodoreta z Cyru, „U Schyłku Starożytności. Studia Źródłoznawcze” 17/18 (2018/2019) s. 61-89.

\section{Tertulian}

Kuźma A., Autorytet Kościoła rzymskiego i jego biskupa w nauczaniu św. Ireneusza z Lyonu, Tertuliana i św. Cypriana z Kartaginy, „,Rocznik Teologiczny” 62/4 (2020) s. 1151-1191.

\section{Wiktor z Wity}

-, Historia prześladowania wandalskiego w Afryce, tł. M. Szada, w: Męczennicy [1], s. 406-479. 


\section{Recenzje}

Eckmann A. (rec.), Bp Jan Śrutwa, Dzieje Kościoła w Starożytności, t. 1: Epoka wielkich prześladowań; t. 2: Kościól w Cesarstwie Rzymskim, Lublin: Towarzystwo Naukowe KUL, 2018 - VoxP 76 (2020) s. 171-172.

Kochanek P. (rec.), Jan M. Wolski, Kultura monastyczna w późnośredniowiecznej Butgarii, Byzantina Lodziensia 29, Łódź 2018, Wydawnictwo Uniwersytetu Łódzkiego, ss. 225 - VoxP 73 (2020) s. 239-244.

Kochanek P. (rec.), Sławomir Bralewski, Symmachia cesarstwa rzymskiego z Bogiem chrześcijan (IV-VI wiek), t. 1-2, Byzantina Lodziensia 27 i 32, Łódź 2018, Wydawnictwo Uniwersytetu Lódzkiego, ss. 312 + IX i 333 + VI - VoxP 73 (2020) s. 244-259.

Kochanek P. (rec.), Kazimierz Ginter, Wizerunek władców w “Historii kościelnej” Ewagriusza Scholastyka, Byzantina Lodzienasia 29, Łódź 2018, Wydawnictwo Uniwersytetu Łódzkiego, ss. 337 - VoxP 74 (2020) s. 199-213.

Kochanek P. (rec.), Олександр Кащук, Монотеліство у Візантї VII століття: доктрина, політикатаідеологіявлади, Львів 2019, ЛНУ імені Івана Франка VoxP 74 (2020) s. 214-217.

Kochanek P., (rec.) Ks. Stanisław Longosz, Opera minora selecta, do druku podali i zredagowali Jan Iluk $i$ Wojciech Stawiszyński, Warszawa: Wydawnictwo Naukowe „Sub Lupa”, 2019 - VoxP 76 (2020) s. 175-178.

Longosz S. (rec.), Św. Jan Chryzostom, Homilie do Drugiego Listu św. Pawła do Koryntian, przekład z języka greckiego, wprowadzenie i noty ks. Antoni Paciorek, Biblia Ojców 1, Częstochowa: Edycja Świętego Pawła, 2019 - „Seminare” 41/3 (2020) s. $165-169$.

Loska E. (rec.), Marek Kuryłowicz, Rzymskie prawo oraz zwyczaje grobowe i pogrzebowe. Studia i szkice, Lublin: Wydawnictwo Werset, 2020 - „Zeszyty Prawnicze” 20/3 (2020) s. 343-348.

Ludewicz M. (rec.), Ks. Wojciech Kamczyk, Bogowie i demony. Augustyn z Hippony i religijność pogańska późnej starożytności, Studia Antiquitatis Christianae Series Nova 22, Katowice 2020, ss. 168 - VoxP 76 (2020) s. 178-182.

Nabożny M. (rec.), Edward D. Andrews, The Reading Culture of Early Christianity: The Production, Publication, Circulation, and Use of Books in the Early Christian Church, Cambridge: Ohio, 2019 - VoxP 76 (2020) s. 173-175.

Nieścior L. (rec.), Bogdan Czyżewski, Ojcowie Kościoła o Piśmie Świętym, Poznań: Uniwersytet im. Adama Mickiewicza w Poznaniu. Wydział Teologiczny, 2020 „Verbum Vitae” 38/2 (2020) s. 675-677.

Toczko R. (rec.), Ali Bonner, The Myth of Pelagianism, Oxford: Oxford University Press, 2018 - „U Schyłku Starożytności. Studia Źródłoznawcze” 17/18 (2018/2019) s. 243-250. 


\section{Sprawozdania}

Ivasivka V., Św. Paweł jako apostoł na podstawie dziet św. Jana Chryzostoma. Promotor: ks. dr hab. Piotr Szczur, prof. KUL (Lublin); recenzenci: ks. prof. dr hab. Norbert Widok (Uniwersytet Opolski), ks. prof. dr hab. Józef Naumowicz (Uniwersytet Kardynała Stefana Wyszyńskiego w Warszawie) - RT 67/4 (2020) s. 112-116.

Kamczyk W., ,, 1600-lecie śmierci św. Hieronima: biblisty, dogmatyka, polemisty...”. Sprawozdanie ze spotkania Sekcji Patrystycznej przy Komisji ds. Nauki Katolickiej Konferencji Episkopatu Polski (Wigry, 23-25 września 2019), ŚSHT 52/2 (2019) s. 462-464.

Klusek K., Teologiczne aspekty władzy na podstawie „Moralia in Iob” św. Grzegorza Wielkiego. Promotor: ks. prof. dr hab. Jerzy Pałucki (KUL); recenzenci: ks. prof. dr hab. Bogdan Częsz (Uniwersytet im. Adama Mickiewicza w Poznaniu), prof. dr hab. Jerzy Wojtczak-Szyszkowski (Uniwersytet Warszawski) - RT 67/4 (2020) s. 116-120.

Kochanek P., V Ogólnopolska Konferencja Bizantynistyczna z cyklu Wybrane aspekty kultury bizantyńskiej pt. „Bizantyńskie doktryny z zakresu filozofii władzy, teologii politycznej oraz ideologii wojny” (Lublin, 21-22 listopada 2019) - VoxP 73 (2020) s. 263-266.

\section{Wybrane publikacje $z$ zakresu literatury klasycznej}

\subsection{Przeklady}

Arystoteles, Analityki pierwsze. Analityki wtóre, tł. i opr. M.A. Wesoły, Lublin: Polskie towarzystwo Tomasza z Akwinu, 2020.

Diodor Sycylijski, Czas diadochów, Biblioteka Historyczna ks. XVIII, tł. A. Pawlaczyk, red. S. Dworacki, Fontes Historiae Antiquae 48, Poznań: Wydawnictwo Naukowe UAM, 2002 (wydanie dwujęzyczne).

Diodor Sycylijski, Od mitu do historii (Biblioteka Historyczna: Fragmenty ksiag VI-X), tł. S. Dworacki $(\dagger)$ - A. Pawlaczyk, red. S. Dworacki $(\dagger)$,Fontes Historiae Antiquae 50, Poznań: Wydawnictwo Naukowe UAM, 2020 (wydanie dwujęzyczne).

Ficino Marsilio, Kompendium „,Teologii Platońskiej”, przekład i opracowanie Joanna Papiernik, „Studia z Historii Filozofii” 1 (2020) s. 7-24.

Galen, Pseudo-, Czy to, co znajduje się $w$ tonie, jest istota żywa??, t1. R. Sawa, VoxP 74 (2020) s. 157-195.

Hadrian, Epistula Hadriani ,ad Pergamenos”, tł. K. Tadajczyk, „Zeszyty Prawnicze” 20/3 (2020) s. 337-341.

Ksenofont, Ekonomik, tł. D. Tymura, Warszawa: PIW, Teologia Polityczna, 2020. 
Maksymos z Tyru, Trudy i przeciwności przynosza korzyść (Deklamcja XXXIV), tł. M. Szarmach, „Nowy Filomata” 23/2 (2019) s. 143-147.

Oppian, Halieutika. Poemat o rybach i rybakach, tł. K. Bartol, Poznań: Wydawnictwo Naukowe UAM, 2020.

Pawłowski K., Starożytne życiorysy Platona, Warszawa: Wydawnictwo Naukowe UKSW, 2020.

Platon, Państwo, tł. W. Witwicki, Kęty: Wydawnictwo Marek Derewiecki, 2020.

Plutarch, O jedzeniu zwierzat. Mowa pierwsza, tł. D. Miszczyński, w: D. Miszczyński, Sprawiedliwość wobec zwierząt w ujęciu Plutarcha z Cheronei oraz przekład kluczowych źródet do wegetarianizmu wraz z komentarzem. Plutarch, O jedzeniu mięsa. Porfiriusz, O wstrzemięźliwości od jedzenia zwierząt, Warszawa: Wydawnictwo Sub Lupa, 2020, s. 49-58.

Plutarch, O jedzeniu zwierząt. Mowa druga, tł. D. Miszczyński, w: D. Miszczyński, Sprawiedliwość wobec zwierząt $w$ ujęciu Plutarcha $z$ Cheronei oraz przekład kluczowych źródeł do wegetarianizmu wraz z komentarzem. Plutarch, O jedzeniu mięsa. Porfiriusz, O wstrzemięźliwości od jedzenia zwierząt, Warszawa: Wydawnictwo Sub Lupa, 2020, s. 59-66.

Porfiriusz z Tyru, O wstrzemięźliwości od jedzenia zwierząt, tł. D. Miszczyński, w: D. Miszczyński, Sprawiedliwość wobec zwierzą w ujęciu Plutarcha z Cheronei oraz przekład kluczowych źródet do wegetarianizmu wraz z komentarzem. Plutarch, O jedzeniu mięsa. Porfiriusz, O wstrzemięźliwości od jedzenia zwierząt, Warszawa: Wydawnictwo Sub Lupa, 2020, s. 67-226.

Solinus, Gajusz Juliusz, Zbiór wiadomości godnych uwagi albo Polihistor, tł. i opr. B.J. Kłoczek, Kraków: Towarzystwo Wydawnicze „Historia Iagellonica”, 2020.

Syliusz Italikus, Epopeja o wojnie punickiej, t. 1, ks. 1-9, tł. S. Śnieżewski - P. Wolski, Kraków: Towarzystwo Wydawnicze „Historia Iagellonica”, 2020.

Ustawa o władzy Wespazjana/Lex de imperio Vespasiani, tł. K. Kłodziński-P. Śpiewak, Fontes Historiae Antiquae 49, Poznań: Wydawnictwo Naukowe UAM, 2020 (wydanie dwujęzyczne).

\subsection{Opracowania}

Artemiuk P., Sokrates $i$ nowa apologia, „Studia Teologiczne Białystok-Drohiczyn-Łomża”, 38 (2020) s. 33-53.

Browning R., Justynian i Teodora, Warszawa: Państwowy Instytut Wydawniczy, 2021 (wznowienie).

Danek Z., Prawdziwe początki filozofii, Łódź: Wydawnictwo Uniwersytetu Łódzkiego, 2020.

Filipczak P., Biographic Entries on the Governors of Arabia (c. 356-363 AD). An Attempt in Reconsideration of Libanius 'Letters, „Res Historica” 50 (2020) s. 35-53. 
Filipczak P., Namiestnicy rzymskiej Syrii w czasach przełomu (324-361 n.e.), Byzantina Lodziensia 40, Łódź: Wydawnictwo Uniwersytetu Łódzkiego, 2020.

Kluczek A.A., Rok sześciu cesarzy. 253 rok po Chr. w świetle źródeł numizmatycznych, Poznań: Instytut Historii UAM, 2019.

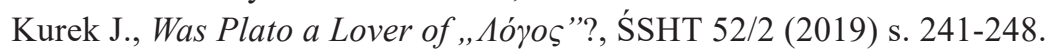

Kuryłowicz M., Rzymskie prawo oraz zwyczaje grobowe i pogrzebowe, Lublin: Wydawnictwo Werset, 2020.

Lengauer W., Dionizos. Trzy szkice, Kraków: Wydawnictwo Homini, 2020.

Liwerska-Garstecka A., Asklepios i medycyna w II w. Metody leczenia w «Świętych mowach» Eliusza Arystydesa, Scripta Minora XIII, Poznań: Wydawnictwo Instytutu Historii UAM, 2020.

Łuć I., Si vis pacem, para bellum - wizja rzymskiej armii i sztuki wojennej w świetle „Epitome rei militaris” Wegecjusza, VoxP 75 (2020) s. 317-344.

Morawski K., Julian Apostata, Sandomierz: Wydawnictwo Armoryka, 2019 (reprint).

Morawski K., Rzymianie i Germanie u schyłku państwa rzymskiego, Sandomierz: Wydawnictwo Armoryka, 2019 (reprint).

Niesiołowski-Spano Ł. - Stebnicka K., Historia Żydów w starożytności. Od Thotmesa do Mahometa, Warszawa: PWN, 2020.

Otto W.F., Dionizjos. Mit i kult, tł. J. Korpanty, wyd. 2, Warszawa: Wydawnictwo Naukowe Sub Lupa, 2020.

Schultz R., Łowcy przygód $w$ dalekich krainach. Wielkie pionierskie podróże $i$ wiedza antyku o świecie, tł. B. Nowacki, Warszawa: Wydawnictwo PIW, 2020.

Siuta T., Datames, opr. K. Królczyk, Poznań: Instytut Historii UAM, 2019.

Smolak M., „Peri hēdonēs”, czyli o przyjemności w ,Etyce nikomachejskiej” (VII 1114) Arystotelesa. Studium egzegetyczne, Kraków: Wydawnictwo UJ, 2020.

Smoraczewski Ł., Administracja diecezji Pontu w późnym Cesarstwie Rzymskim, Poznań: Instytut Historii UAM, 2020.

Supady J., Medycyna w czasach antycznych i średniowiecznych, Tarnów: Wydawnictwo Biblos, 2020.

Szubert B., Starożytna Arabia w świetle źródeł greckich, część 1: Epoka archaiczna, klasyczna i hellenistyczna, Wrocław: Wydawnictwo Chronicon, 2020. 